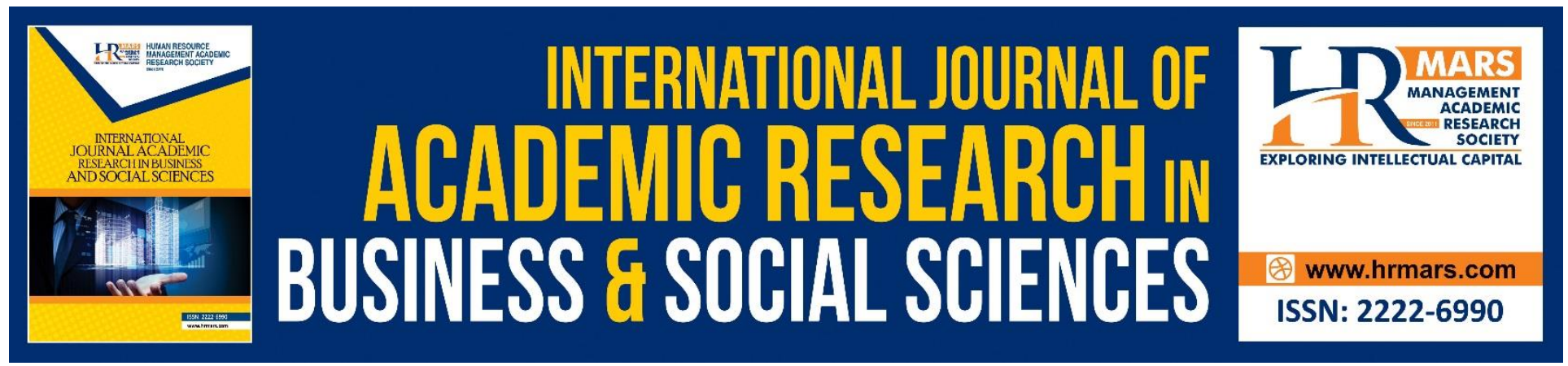

\title{
Cyber Addiction and the Impact towards Gen Zers Attitude in Learning
}

\section{Sharifah Raudzah S Mahadi}

To Link this Article: http://dx.doi.org/10.6007/IJARBSS/v8-i12/5433

DOI: $10.6007 /$ IJARBSS/v8-i12/5433

Received: 30 Nov 2018, Revised: 23 Dec 2018, Accepted: 29 Dec 2018

Published Online: 12 Jan 2019

In-Text Citation: (Mahadi, 2018)

To Cite this Article: Mahadi, S. R. S. (2018). Cyber Addiction and the Impact towards Gen Zers Attitude in Learning. International Journal of Academic Research in Business and Social Sciences, 8(12), 2222-2228.

\section{Copyright: (C) 2018 The Author(s)}

Published by Human Resource Management Academic Research Society (www.hrmars.com)

This article is published under the Creative Commons Attribution (CC BY 4.0) license. Anyone may reproduce, distribute, translate and create derivative works of this article (for both commercial and non-commercial purposes), subject to full attribution to the original publication and authors. The full terms of this license may be seen

at: http://creativecommons.org/licences/by/4.0/legalcode

Vol. 8, No. 12, 2018, Pg. 2222 - 2228

http://hrmars.com/index.php/pages/detail/IJARBSS

JOURNAL HOMEPAGE

Full Terms \& Conditions of access and use can be found at http://hrmars.com/index.php/pages/detail/publication-ethics 


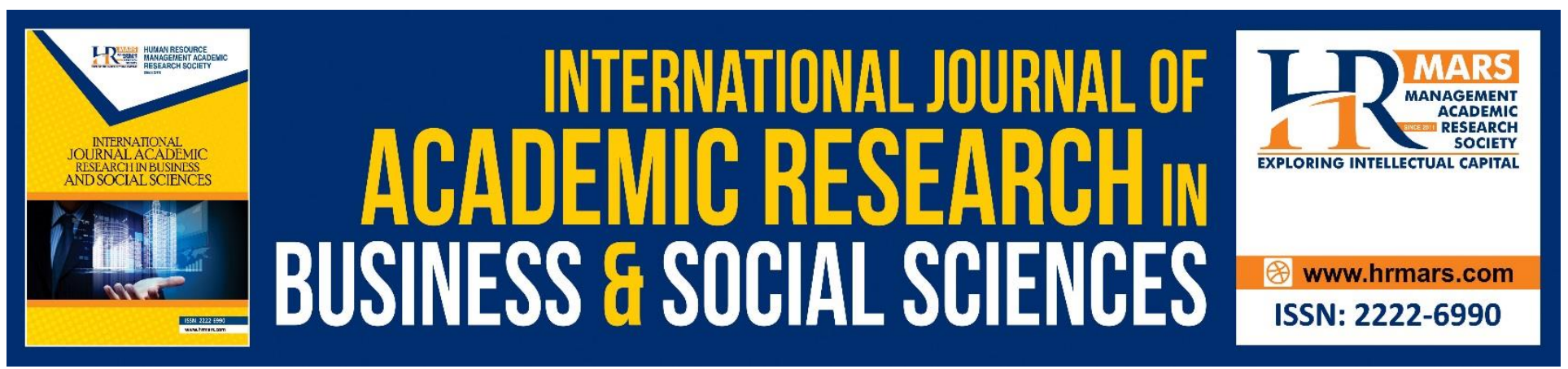

\title{
Cyber Addiction and the Impact towards Gen Zers Attitude in Learning
}

\author{
Sharifah Raudzah S Mahadi \\ Faculty of Art \& Design, Universiti Teknologi MARA, Perak Branch, Seri Iskandar Campus, \\ 32610 Perak, MALAYSIA
}

\begin{abstract}
In today's contemporary living, the proliferation of internet has become a major component to complete each individual, especially the $Z$ generation. They had been exposed to technological advancements especially in the virtual world since birth. Now, this generation has entered the world of higher education. Educators now face challenges in educating them, primarily because of their attitude issues. This Gen Z has been labeled as spoilt, rebellious and selfish. Therefore, the purpose of this study is to identify that major problem in their attitude and to investigate whether cyber addiction plays a major role in this problem hence affecting their studies. This study will involve quantitative method by using semi-structured interview and Likert scale questionnaire. The interview involving 65 educators and will be recorded and analyzed, while as the questionnaire will be handed out to 300 undergraduates (born in year 1997 above) for later analysis through SPSS and AMOS version 22. Results achieved will prove as solid evidence that when these young adults are left unmanaged in the cyber world it may prove to create negative impacts in the future. Parents in particular, must focus concern and awareness in them so as our future leaders will not continue to be distracted and engrossed to the point of losing their faith. This study is also parallel to one of the tier in the 11th RMK emphasizing that the 21st century graduates are to be apt leaders, ethically and morally.
\end{abstract}

Keywords: Attitude, Learning, Gen Z, Cyber Addiction.

\section{Introduction}

This century, the world has been powered by technological greatness, developing vast and fast in everyday life. This technological advancement has already accomplished Industrial Revolution 4.0 where it has elevated the proficiency of management and information transfer digitally. Today's digital world is no longer foreign especially to the younger generation that is called Gen Z or iGen (Internet Generation). According to Ozkan, M. \& Solmaz, B (2015), these Gen Z are different from previous generations, they are network youths in regards to them being born into a world already advanced in technological advancements like smartphones and the world wide web. They too are 
inseparable from their internet equipped smartphones which compliment their daily lives. This has become a worrying issue for the country especially in education and the impact it created in family issues. Prolonged usage of internet and gradual exposure to negative elements has stimulated them towards cyber addiction. This cyber addiction can been identified when they exhibit the inability to control the urge to surf the net and the anxiety it provokes as if life without internet will cause disruptions in their social and family life. (Young, 2004).

Today, the world has often been left aghast by news of rape, bully, murder and cybercrimes by this young generation. This arises extreme anxiety to many, especially parents and educators, because this young generation is still under aged and in close relations with them. In the education contexts, educators found that generation $Z$ has a distinctive attitude different from previous generations, where they seem disinterested, dispassionate, disrespectful and egotistical. These already resulted a negative impact during lessons. This situation will be made worse if not nipped in the bud. Therefore, this study is fitting to prove if uncontrolled cyber-use induced addiction will give negative repercussions to their moral and attitude. Gen $\mathrm{Z}$ is the aspiration for the country to lead in the future. In coincidence with the hope of the government to shape these youngsters into morally correct, dynamic thinkers and leaders, this study can provide preliminary steps to create awareness in those already subjected, to hold back and not be too consumed to unbeneficial things on the world wide web.

\section{Hypotheses}

1) Time management among Gen $Z$ is weak because of the cyber addiction.

2) Communication skills among Gen $Z$ are weak because of the cyber addiction.

3) Performance among Gen $Z$ decreases because of the cyber addiction.

4) Ethic among Gen $Z$ decreases because of the cyber addiction.

All hypotheses will be validated from data analysis to show that cyber addiction is the driving force behind the attitude problem in Gen $\mathrm{Z}$ in learning context.

\section{Research Questions}

1) What are the attitude problems among Gen $Z$ in learning?

2) How Gen Z's attitude with cyber addiction is correlated in learning?

\section{Literature Review}

\section{Attitude Theory}

According to Mahadi, S.R.M., Jamaludin, N.N. \& et.al (2016), attitude refers to feeling, manners and tendency or orientation of mind towards a person or thing. Attitude can also influence behavior. Theory of attitude consists of three major components; affective, behavioral and cognitive. These components are referred to as ABC model. Danial Katz (1960), he has come out with four functions of attitude of an individual which include knowledge, self/ego expressive, adaptive and egodefensive. In definition to attitude, sociologically it refers to verbal expressions as an intention to act and attempt to reduce prejudice and discrimination by changing behavior (Chaiklin, 2011). Attitude 
can also be simplified as a reflection of behaviour. A very simple situation to relate to attitude is that of a person who possesses a good attitude towards people around him, positively it will also have influences on them too. $A B C$ model plays an important role in this study to postulate the attitude issues occurring in the learning process nowadays among Gen Z.

\section{Gen Z Characteristic}

Those who were born as of 1996 and after are classified as Gen Z. They are also known as iGen (internet generation). Gen Zers are exposed to the technology from the day they were born especially to the internet network. According to Ozkan, M. \& Solmaz, B. (2015), this Gen Z is different from the previous generations, because they are network youths, in regards to them being born into a world already advanced in technological advancements like smartphones and the world wide web. Today, an individual is driven to own a smartphone together with internet connection. This is because of the trend factor of the advanced technology enables people around the world to connect at anytime and anywhere. Gen Zers also believes that everything they needed or curious about can be looked up from the internet using the search engines. Compared to previous generations, Gen Z prefers to cool products instead of experience. They are so advanced and their cyber spending time also increases. Hawkins (2015) stated that they are more than 52 percent from the estimation of Gen Zers spent their day with a significant amount of "screen time".

\section{Teaching \& Learning Challenge}

Gen Zers are entering the university and they are very important to the institution today. Seeming that their characteristics are different from the previous generations, the educators have prepared new teaching and learning style and learn to adapt the advancement technology parallel to their needs. According to Fudin (2012), Gen Zers are more interested to get information that they required straight, instead of reading the whole text. Online, they are very responsive to the hyperlinks made to the certain keywords they were searching for, usually within a few seconds.

In addition, Rothman (n.d.) claimed that generation Z's brains have wired to become a sophisticated, complex visual imagery and has driven their visual ability into a highly superb form of learning especially in visual forms of learning. Auditory learning is not a Gen Zers' favourite. However, they gravitate more towards interactive games, collaborative projects, advanced organizers, challenges, and anything that they can try and visualize.

In this study, researchers believe that all educators have prepared and practically apply the advanced teaching technique as required to balance the students' needs. However, in terms of attitude amongst this $Z$ generation towards learning, they found that they are not fearful to try and explore anything that is new to them. They take opportunities to research whatever interests them, especially via online (Fudin, 2012). This has showed that if they desire for something, they would work for it. In learning, if they are not interested, they refuse to take part in the game. They lack punctuality, performance and sometimes they shun themselves from the society. This is the situation where educators need to overcome and find the factors that are influencing them and consequently distracting the learning process. 


\section{Cyber Addiction}

The use of internet has become a necessary thing to have today in order to complete a person's daily routine. According Tsai \& Lin (2001), individuals can handle and solve their needs such as making hotel reservations, looking for information, online shopping, money transferring or anything at the tip of their fingers as long as it is connected to the internet. Plus, the existence of internet can save a lot of time when searching for any information and to keep up to date with the news. However, the internet can also influence a human life from better to worse when it turned into unhealthy use (Davis, 2001). The misuse of internet can slowly lead to cyber addiction. This cyber addiction can be identified when they exhibit the inability to control the urge to surf the net and the anxiety it provokes as if life without internet will cause disruptions in their social and family life (Young, 2004). Khazaei, F., Khazae, O. \& Ghanbari-H, B. (2017) also claimed that internet addiction refer to the lack of control of internet use including the addiction towards online games and social media network. Suissa, A.J. (2015); Levard and Soulas (2010) has proved that the milestone of Facebook (one of social media application) has exceeded to one billion users worldwide.

As has been noted, cyber addiction is a crucial thing happening amongst the Gen Zers now. Parallel to issues in education context, the students' attitude towards learning, such as time management, performance, communication skills and ethics has shown a negative sign during teaching and learning processes. The impact is appalling to those affected by cyber addiction because it can ruin family bonds, health, education (drop performance), career problem and relationship (Huang, Li, \& Tao, 2010). Besides, cyber addiction can also strain communications between two people (face to face) and opens opportunity to provoke negative feeling such as depression and loneliness (Yao \& Zhang, 2014). Thus, the purpose of this study is to come out with a model of Gen Zers attitude in learning that is most positively showing relationship with cyber addiction issues in Malaysia.

\section{Methodology}

In order to achieve the research objectives, this study will be conducted based on the following phases as follow:

Objective 1: Phase 1- Identifying the attitude problems and issues amongst Gen $\mathrm{Z}$ in learning Objective 2: Phase 2- Analyzing the attitude problems and issues and their correlation with cyber addiction that affected learning

Firstly, a theoretical study will be conducted through the collection of relevant secondary data of attitude and cyber addiction. Thereafter, the researcher will develop interview questionaire and conduct the interviews with educators who are randomly picked from 5 departments in Art and Design Faculty of Universiti Teknologi MARA, Seri Iskandar campus. All the data are recorded and analyzed. Next, the researcher will develop questionnaire that is related to the attitude and issues amongst Gen Z highlighted from the interview sessions data. The questionnaire will be divided into 4 major attitudes in learning. These are time management, performance, communication skills and ethics. For every major attitude there will be 5 to 6 questions. The development of the questionaire (items) will follow the Attitude Theory major components (affective, behavioral and cognitive). Simultaneously, the questionnaire will include Young's Internet Addiction Test questions in order to measure their level of addiction. 
This questionnaire will be distributed to 300 undergraduate students who were born in year 1997 and above. A pilot test will also be conducted at first in order to check the reliability and validity of the questionnaire.

Second phase is the data from the questionnaire will be run through SPSS as database. Then by using AMOS version 22, an observed scale characteristics and the association between variables will be investigated and normality assumption will be checked using skewness and kurtosis scores. In addition, Pearson correlation and Spearman correlation will also be conducted to see the direction of the relationship, which is indicated by the sign of the coefficient; a + sign indicates a positive relationship and a - sign indicates a negative relationship, if Gen Zers attitude in learning is affected by cyber addiction.

\section{Conclusion}

This research outcome will be beneficial to the education system, parenting guide and everyone in Malaysia in general. In other words, the result will useful as a prevention measure by creating awareness. Besides, this study will also give an insight to researchers interested in this issue regarding ways to overcome the cyber addiction among new generation in order to balance their daily life towards becoming a better person in regards to their attitude. Once this issue is detected and action is taken, our government must be proud and relieved that this new generation with a good attitude and moral values are able to raise Malaysia for future ventures worldwide.

Through one of its strategic core of the 11th RMK is in regards of graduate educations in the 21st century. Here the government emphasized on producing many graduates who are ready to face a more dynamic future while maintaining high morale and ethics. With this decision, it shows that the results from this study will help as a preliminary step and untangles the problems arising in this age so as students will not continue to be drifting without control and preoccupied with the internet or social media. Graduates of today will be the country's assets in the future. Therefore, they must prepare themselves in all aspects, especially in their attitude and their moral.

\section{Corresponding Author}

Sharifah Raudzah S Mahadi

Universiti Teknologi MARA, Perak Branch, Seri Iskandar Campus, 32610 Seri Iskandar, Perak, Malaysia.

Email: sharifahraudzah@gmail.com / raudzah750@perak.uitm.edu.my

\section{References}

Chaiklin, H. (2011). Attitudes, Behavior, and Social Practice. The Journal of Sociology \&Social Welfare, 38(1), Article 3.

Davis, R. A. (2001). A cognitive-behavioral model of pathological Internet use. Computers in Human Behavior, 17(2), 187- 195. http://dx.doi.org/10.1016/S0747-5632(00)00041-8.

Fudin, S. (2012, March 29). Gen Z \& what does it mean in your classroom? USCRossierOnline. Retrieved from https://rossieronline.usc.edu/gen-z-what-does-it-mean-in-your-classroom2 
INTERNATIONAL JOURNAL OF ACADEMIC RESEARCH IN BUSINESS AND SOCIAL SCIENCES

Vol. 8, No. 12, Dec, 2018, E-ISSN: $2222-6990$ (C) 2018 HRMARS

Hawkins, B. D. (2015, July 13). Here comes generation Z: What makes them tick? Neatoday.org. Retrieved from http://neatoday.org/2015/07/13/here-comes-generation-zwhat-makes-themtick.

Huang, X. Q., Li, M. C., \& Tao, R. (2010). Treatment of internet addiction. Current Psychiatry Reports, 12(5), 462-470.

Katz, D. The Functional Approach to The Study of Attitude. Public Opinion Quarterly, 24(Summer 1960), pp.163- 204.

Khazaei, F., Khazaei, O. \& Ghanbari-H, B. (2017). Positive psychology interventions for internet addiction treatment. Computers in Human Behavior, 72 (2017), $304-311$.

Levard, O., \& Soulas, D. (2010). Facebook: Mes amis, mes amours...des emmerdes! Paris: Michalon Editions.

Mahadi, S.R.S., Jamaludin, N.N., Johari, R., \& Fuad, I.N.F.M. (2016). The Impact of Social Media among Undergraduate Students: Attitude. Procedia-Social and Behavioral Sciences, 219 (2016) 472 479.

Ozkan, M. \& Solmaz, B. (2015). Mobile Addiction of Generation Z and its Effects on Their Social Lifes. Procedia - Social and Behavioral Sciences, 205 (2015), 92 - 98.

Suissa, A. J. (2015). Cyber addictions: toward a psychosocial perspective. Addictive Behaviors, 43(2015), 28--32.

Tsai, C. C., \& Lin, S. S. (2003). Internet addiction of adolescents in Taiwan: An interview study. CyberPsychology \& Behavior, 6(6), 649-652.

Yao, M.Z., \& Zhong, Z.J. (2014). Loneliness, social contacts and internet addiction: A cross-lagged panel study. Computers in Human Behavior, 30, 164-170.

Young, K. S. (2004). Internet addiction a new clinical phenomenon and its consequences. American Behavioral Scientist, 48(4), 402-415. http://dx.doi.org/10.1177/0002764204270278. 